\title{
IMAGINARIO ALIMENTICIO Y COMUNIDAD RURAL EN LA POESÍA CHILENA DE LOS AÑOS CINCUENTA DEL SIGLO XX*
}

\author{
Naín Nómez ${ }^{* *}$
}

\section{Resumen}

El presente artículo incursiona en la poesía de los años cincuenta del siglo XX en Chile, a partir de la revisión del imaginario de los alimentos en su relación con comunidades rurales, especialmente de la zona central del país, que se representan como comunidades desaparecidas o perdidas, lo que implica así mismo pérdida de las costumbres, las tradiciones y las identidades locales. Al mismo tiempo, en los textos poéticos se muestra el sistema alimentario del mundo urbano como un espacio enajenado y extranjerizante, ligado a identidades fragmentadas y marginadas. Los poetas seleccionados para el análisis son fundamentalmente aquellos para quienes la dicotomía entre campo y ciudad se agudiza, entre ellos, se encuentran Violeta Parra, Jorge Teillier, Efraín Barquero, Alberto Rubio, David Rosenmann-Taub y Delia Domínguez.

Palabras clave: poesía, Comunidad rural, Identidad local, Imaginario alimenticio

\section{NUTRITIONAL IMAGINARY AND RURAL COMMUNITY IN CHILEAN POETRY OF TWENTY CENTURY' FIFTIES}

\begin{abstract}
The current article inquiry into the poetry of the twenty century fifties in Chile, considering the examination of the food imaginary relating to rural communities, specially those of the country central zone, that are represented as lost and vanished communities, which impliestherefore lost of customs, traditions and local identities. At the same time, in the poetic texts the food system of the urban world is seen, as an alienated and foreign space, linked to fragmented and marginalized identities. The poets selected in this analysis are fundamentally, those for whom the country and city dichotomy is more acute, among them, Violeta Parra, Jorge Teillier, Efraín Barquero, Alberto Rubio, David Rosenmann-Taub y Delia Domínguez.
\end{abstract}

Key words: poetry, Rural community,Local identity,Nutritional imaginary.

Este artículo se enmarca dentro del proyecto Fondecyt No. 1120264 titulado Las comidas y las bebidas en la poesía chilena, cuya investigadora responsable es la Dra. Magda Sepúlveda Eriz de la Pontificia Universidad Católica de Chile y del cual soy co-investigador. Una primera versión se presentó en el XIX Congreso Internacional de la Sociedad Chilena de Estudios Literarios (SOCHEL), Concepción, noviembrede 2014. La versión actual fue preparada como artículo.

* Ph.D. en Literatura. Académico de Excelencia de la Universidad de Santiago de Chile, Santiago, Chile.nain.nomez@usach.cl 


\section{Nuestro tema}

Las posturas estéticas de los poetas de los años cincuenta del siglo XX en Chile se diversifican a partir de una variedad de líneas temáticas $\mathrm{y}$ de reformulaciones formales que conforman una ruptura transversal frente a las vanguardias. La diversidad de posiciones nuevas en el campo literario, y especialmente en el poético, se concentran en la exposición cada vez más marginal del poeta, quien critica desde sus textos al sujeto moderno y al mundo urbano simbolizado en la burguesía ascendente de cuya realidad se distancia, a partir de la ironización del discurso o la recuperación deun mundo primigenio perdido cada vez más inalcanzable. Entre las diversas posturas críticas, recogemos aquí la del llamado «Larismo» con sus distintas prácticas poéticas, que aboga por la nostalgia de un mundo rural perdido que se vuelve a instalar en el imaginario poético y que se complementa con un cierto imaginario alimenticio, que materializa un elemento importante de esa comunidad desaparecida. En este sentido, el objetivo de este trabajo es focalizar su análisis en algunos poetas del periodo, que si bien cierran su relación con las vanguardias, lo hacen desde una posición de búsqueda un tanto anacrónica hacia el origen (arcadia, paraíso) perdido. En ellos, se recupera la tradición de una ruralidad en retroceso que ya habían instalado algunos poetas de comienzos del siglo XX (Jerónimo Lagos, Jorge González Bastías, Carlos Préndez Saldías, Carlos Acuña), pero solo tangencialmente, porque se trata más bien de un repliegue frente al mundo urbano donde el sujeto se siente cada vez más aislado y fragmentado. De este modo, el refugio en el mundo rural es más bien el intento de recuperar una naturaleza distanciada y reprimida por las nuevas formas de habitar el mundo. Frente a la modernidad en crisis, estos poetas optan por replegarse hacia formas artesanales de vida que se imbrican con el deseo de un paraíso vedado que sigue existiendo en la memoria. Este planteamiento ha sido desplegado en varios trabajos del autor relacionados con el análisis de la poesía de los cincuenta en Chile (2004, 2006, 2007 y 2008) que pueden consultarse en la bibliografía al final del trabajo. Lo nuevo en este caso, es la relación que los poetas establecen entre la comunidad perdida, el arraigo rural y la simbología de los alimentos, a través de cuyo imaginario la patria del origen devuelta por la memoria, se hace realidad.

De esta manera, el artículo se estructura retomando algunos planteamientos que se han hecho en trabajos anteriores sobre el amplio 
abanico del periodo de los cincuenta, su contexto político y social, la genealogía de los principales poetas y las líneas que desarrollan. En una segunda sección, analizamos algunos lineamientos críticos y teóricos sobre el imaginario de los alimentos y buscamos su articulación con los discursos poéticos del periodo. Finalmente procedemos a analizar la manera como los poetas reescriben, describen e inscriben el imaginario alimenticio, en una identidad comunitaria que se opone a las identidades urbanas fragmentadas, degradadas, marginadas y desarraigadas. Consideramos aquí fundamentalmente textos de Violeta Parra, Jorge Teillier, Efraín Barquero, Alberto Rubio, David Rosenmann-Taub y Delia Domínguez, aunque también se mencionan otros autores del periodo.

\section{Bitácora de la poesía de los cincuenta}

El periodo de los cincuenta fue un momento fundamental en la producción literaria chilena, especialmente en el ámbito de la poesía. De las rupturas de las vanguardias estéticas y políticas que relevaron los discursos fundamentales del arte mundial y latinoamericano entre los años veinte y treinta, quedaron en Chile, además de las imponentes figuras de Pablo Neruda, Pablo de Rokha y Gabriela Mistral, los ecos tardíos de los mandragoristas del año 38 (Braulio Arenas, Enrique Gómez Correa, Teófilo Cid) y la continuidad de algunos poeta epigonales, pero residuales y tardíos, como es el caso de Rosamel del Valle, Humberto DíazCasanueva, Eduardo Anguita, Omar Cáceres, Jorge Cáceres y Gustavo Ossorio, entre otros. Y si bien la obra de estos poetas fue importante ya que marcaron un reciclamiento sostenido de los discursos anteriores con experimentaciones que dinamizaron ciertas líneas simbolistas, la lucha por la hegemonía poética empezó a darse con las nuevas promociones que pedían aire y vida cotidiana.

Esta especie de repliegue discursivo y temático frente a los cánticos trascendentes de la vanguardia, se desenvuelve con una intensa necesidad de comunicación con el mundo, el que se acentúa con los llamados «poetas de la claridad», marcada por un lado por la publicación de Cancionero sin nombre de Nicanor Parra en 1937 y por la antología Ocho nuevos poetas chilenos, realizada por Tomás Lago en 1939. Entre los poetas nuevos figuraban además de Nicanor Parra, Óscar Castro, Victoriano Vicario, Luis Oyarzún y Alberto Baeza Flores. Con las vanguardias aprendimos a entender la modernidad como parte de una obsesión por 
lo nuevo, lo contingente y lo transitorio; como una ruptura continua que tenía al frente la idea de un progreso indefinido, pero también como un fenómeno que acarreaba su propia decadencia y corrosión al cuestionarel reino de lo divino y desencantarse del mundo humano. Pero el exceso discursivo había terminado por esconder la realidad que se quería mostrar para quedarse solamente con el simbolismo exacerbado del lenguaje. Cuando Nicanor Parra en los años cincuenta, con gran intuición alude a la necesidad de re-ligar el arte con la vida, está devolviendo al poeta moderno aquello que se propusieron Charles Baudelaire y Arthur Rimbaud en el origen de su fractura con el mundo burgués. La vida no era esa alienación del artista moderno separado de su origen, sino algo que venía de más lejos y que había que rescatar desde el otro lado de la historia: el lado oscuro, obsceno, marginal, degradado.

Hay un contexto nacional e internacional al que no son ajenos artistas, escritores y poetas, aunque no necesariamente incida en sus producciones. En el ámbito histórico de los cuarenta y los cincuenta, acontecimientos como la Guerra Fría y la dicotomía ideológica, los populismos latinoamericanos y la ruptura de la estabilidad política en Chile contrastan con hechos más positivos como el fin de la Segunda Guerra, la política democratizadora de los Frentes Populares, la política económica de un Estado que incentiva la industrialización, la aparición de nuevos partidos como la Democracia Cristiana y el ascenso de los movimientos sociales. En los años cuarenta se reformula el modelo económico chileno que tiene cada vez menos autonomía del capitalismo mundial, agudizando la crisis del Estado hacia 1955 cuando la inflación se desata y la economía se estanca. Mientras grandes sectores sociales reivindican sus derechos económicos y sociales (por ejemplo el voto definitivo de las mujeres), los trabajadores urbanos pierden poder adquisitivo, la agricultura no crece y más de un tercio de los niños no asiste al colegio. La inflación llega en 1956 al 86\%, la más alta registrada hasta ese momento en la historia del país. En este ambiente los escritores polemizan y toman partido, preferentemente por posiciones de cambio y transformación social, a veces militando en partidos de centro o de izquierda, a veces como compañeros de ruta o simples testigos críticos. Muy poco después, en 1959, la revolución cubana provocará adhesiones y rechazos aun más radicales en las posturas críticas de los artistas y escritores chilenos. 
El campo literario chileno del momento y las posiciones de los autores dentro de él (autores, críticos, editoriales, periódicos, revistas, agentes, instituciones culturales, etc.), es un campo en disputa en donde coexisten diversas tendencias, grupos y sensibilidades (Bourdieu, 1995). Viven y escriben poetas de viejo cuño nativista, criollista o modernista como Diego Dublé Urrutia, Jerónimo Lagos, Carlos Préndez Saldías y Daniel de la Vega, junto a poetas más jóvenes pero aun nostálgicos de un mundo rural y pueblerino en retirada, como Alejandro Galaz, Hermelo Aravena Williams o Carlos Collins Bunster, o vates articulados a las coyunturas políticas como el caso de Juvencio Valle, Luis Merino Reyes, Olga Acevedo y Alberto Baeza Flores. La modernidad en crisis se reordena bajo nuevas formas sistémicas (capitalismo; imperialismo; transnacionalización; populismos, socialismos y comunismos diversos en Yugoeslavia, Italia y China; alternativas económicas regionales y continentales), que permiten retomar las utopías sociales en la historia, lo que repercute también en los discursos literarios. Esto se representa en Chile en los cantos apoteósicos y mitopoéticos de Pablo Neruda y Pablo de Rokha en los años cincuenta.

A partir de estos contextos, una parte importante de los nuevos poetas pretende clausurar el complejo entramado del imaginario vanguardista. Esa es la tarea que emprende Parra y que desde distintas vertientes estéticas, acompañan y continúan poetas como Gonzalo Rojas, Enrique Lihn, Jorge Teillier, Delia Domínguez, Efraín Barquero, Armando Uribe, Alfonso Alcalde, Rolando Cárdenas, Stella Díaz Varín, Miguel Arteche y David Rosenmann-Taub, entre otros. Desde la obra temprana de Parra se pueden vislumbrar al menos tres posturas: 1 . La del poeta que critica la urbe moderna desde un sitio marginal y degradado, que se vislumbra en textos como «El gato muerto», «La niña engañada» $\mathrm{O}$ «La niña testaruda» de Cancionero sin nombre, pero más claro en «Autorretrato» o «Los vicios del mundo moderno» de Poemas y antipoemas (1954). 2. La del sujeto que ironiza su situación, construyéndose innumerables máscaras transitorias; aquí casi todos los poemas de los libros mencionados antes y 3. La del poeta que se hace cargo del mito del origen perdido a partir de la imposibilidad del retorno y que está ya en el poema «Hay un día feliz», publicado en 1954. Esta última es la que nos interesa en este texto, porque se vincula con la poesía del Lar y la nostalgia por un mundo rural perdido, cuya fuente de reconstrucción es la memoria a través de un repliegue afectivo frente a un mundo adverso. Sus representantes más visibles dentro de sus diversidades y estéticas específicas son: Jorge 
Teillier, Efraín Barquero, Luis Vulliamy, Rolando Cárdenas, Alberto Rubio, Marino Muñoz Lagos, Pablo Guiñez, Delia Domínguez y en alguna medida también David Rosenmann Taub, Alfonso Calderón, Violeta Parra y Miguel Arteche. Estos últimos, si bien no se integran a las estéticas láricas, escriben un puñado de poemas que reflejan este sentimiento de retorno a una comunidad arcádica, que se representa como un paraíso perdido frente a las vicisitudes del proceso moderno. El poeta de raigambre lárica, al revés de sus antecesores ruralistas de comienzos del siglo XX (Augusto Santelices, Jorge González Bastías, Carlos Acuña, Jerónimo Lagos Lisboa o Carlos Préndez Saldías), representa una nostalgia del desarraigo de la infancia, pero sin retorno. Es un paraíso perdido que ni siquiera la memoria es capaz de retener, porque se convierte en pura imagen soñada. En este punto es necesario aclarar que el concepto de lo «lárico» se atribuye fundamentalmente a la obra de Jorge Teillier, pero algunos de los otros poetas del periodo, como hemos señalado, se acercan a este tópico de una manera más tangencial y distanciada.

\section{El imaginario de los alimentos y la comunidad perdida en la poesía chilena moderna}

La alimentación como imaginario y metáfora de las relaciones sociales, políticas y económicas de una sociedad se despliega en todos los ámbitos de la vida humana, siendo el arte como expresión central de la cultura, uno de los lugares donde el lenguaje alimenticio adquiere un papel relevante. En este sentido, la literatura y especialmente la poesía, han desarrollado históricamente una representación de los alimentos, que se fusiona con las maneras como los autores han visualizado su sociedad y las relaciones que establecen los sujetos para dialogar con ella. Para Claude Levy Strauss (410-432), la nutrición es la forma básica que caracteriza la cultura de cada grupo. A partir del análisis de una serie de culturas, el autor concluyó que el alimento en las comunidades humanas se ofrece en tres estados principales: crudo, cocido y podrido. Lo crudo sería el estado no marcado y tiene afinidad con lo asado y la cocina a la parrilla que serían la primera técnica de transformación del alimento. Lo cocido es la transformación de lo crudo y lo podrido su transformación natural. Esto da origen a una doble oposición: la de lo elaborado y lo no elaborado y la de la cultura versus la naturaleza. A estos elementos 
habría que agregar lo hervido, lo frito y lo ahumado también más cerca de la cultura. Pero todo ello delimita un campo semántico desde fuera, es decir, de cada cultura en particular y de cada época singular, puesto que en ciertas circunstancias lo crudo y lo asado son también representaciones de sofisticación cultural. Para Mijail Bajtín en La cultura popular en la Edad Media y el Renacimiento (1974), la idea del banquete o la gran comida popular plantea un hiperbolismo positivo y un tono triunfal y alegre, tal como apreciamos por ejemplo en textos de Pablo de Rokha o Pablo Neruda. Para ello, el autor se remite al texto de Rabelais, Gargantúa y Pantagruel (uno de los autores favoritos de De Rokha), analizando las imágenes del cuerpo grotesco durante el banquete y el motivo de la boca abierta y la deglución. En su estudio, el crítico muestra hasta qué punto las imágenes de la alimentación se fusionan con el cuerpo y las marcas de la reproducción: fertilidad, crecimiento y alumbramiento. La absorción de alimentos en el banquete se relaciona con las fiestas y la imagen grotesca del cuerpo, pero también con la palabra y la sabia conversación: «en el comer...el cuerpo se evade de sus límites; traga, engulle, desgarra el mundo, lo hace entrar en sí, se enriquece y crece a sus expensas [...] El hombre degusta el mundo, siente el gusto del mundo, lo introduce en su cuerpo, lo hace una parte de sí mismo» (253). El banquete rabelesiano que describe Bajtín, puede verse no sólo en los poetas ya mencionados, sino que deriva hacia las instalaciones de varios poetas de los cincuenta como veremos a continuación (Barquero, Rubio y Lihn, entre ellos). El planteamiento de Bajtín resulta sumamente válido para analizar la manera como los poetas de los cincuenta articulan la relación entre el trabajo y el comer colectivo, el «vínculo esencial con la vida, la muerte, la lucha, la victoria, el triunfo, el renacimiento» (253). Bajtín coincide con Pierre Mayol, para quien «el vino y el pan tienen su lógica propia, su verdad, su invencible aspiración a la superabundancia, el inherente matiz indestructible de alegría y de triunfo victorioso» (262; cursivas originales en el texto). Mayol, quien escribe en conjunto con Michel de Certau y Luce Giard los dos tomos de La invención de lo cotidiano (1996, 1999), señala que: «hay dos alimentos que 'acompañan' la comida de comienzo a fin y se acomodan a cada momento de la serie: el pan y el vino... Son pues la base de la cocina; es en lo que debe pensarse en primer término antes de cualquier otra decisión gastronómica» (Tomo II 87). Agrega que «mientras el respeto por el pan habla de los invitados, el vino tiene una marca social de destemplanza y celebración. En este sentido, el pan y 
el vino representan el sacrificio y la solidaridad, el reencuentro con la memoria, la celebración, las nupcias, el regocijo del encuentro» (87-102). ${ }^{1}$ José Bengoa (1996), por su parte, señala que en Chile «lo propio» está profundamente ligado a lo rural. Y agrega:

Chile, al igual que muchas otras sociedades, posee la sensación de haber perdido parte de su identidad [...] A ello se refiere el concepto de comunidad: algo que une a las personas fuera del mercado, un conjunto de significados que están implícitos en el sentido que se les otorga a las palabras, a los gestos, a los silencios aprendidos y a la capacidad de producir -y reproducir- nuevos gestos, nuevos significados comprendidos por todos. (21-3)

Y remata: «la cultura de la modernización compulsiva se opone a la cultura de la identidad» (25). El autor paraleliza las identidades rurales desarrolladas durante el siglo XX con algunos proyectos poéticos que las incluyen:

Algún día entenderemos el mestizaje rural que se fue formando en largos depósitos en el secano costero, en los valles internos, en esa mitad del país, en esas provincias del sur agrícola. Entenderemos el Parral de Neruda, el Elqui de Gabriela, el Chillán de la Violeta, de Nicanor y de don Roberto, el Licantén de De Rokha... (35)

Resulta también indudable para nosotros, que el rescate de los alimentos que desarrollan además varios de los poetas que escriben en los cincuenta, se relaciona con este miedo de perder la identidad, lo que produce un sentimiento de nostalgia por el mundo de un Chile rural perdido, soslayado o marginado.

Magda Sepúlveda ha reiterado en varios textos ${ }^{2}$, que hay un grupo de poetas que trabaja las comidas y bebidas como patrimonio local,

El pan y el vino aparecen permanentemente en las obras de varios poetas de los cincuenta. Es singularmente relevante en Barquero (con un libro titulado El pan y el vino del 2008), en Lihn, en Alcalde, en Arteche, entre otros. Además están en muchos textos de poetas anteriores como Mistral, de Rokha y Neruda.

2 Sepúlveda $(2013,2014)$ ha señalado que en la poesía chilena el signo culinario forma cuatro grandes grupos: 1. La construcción de comunidades alrededor de la comida; 2 . El patrimonio provinciano y/o rural como defensa frente al mundo urbano (tendencia que privilegiamos en este trabajo); 3 . Los deseos caníbales entre diversas subjetividades y; 4 . Los linajes relacionados con el hambre y el sacrificio humano (2013, 151-166; 2014, 199-213). 
en donde se «destaca la enseñanza de los preparados y las maneras en la mesa con su protocolo codificado, como sucede con los platos y brebajes de la zona central» («Ñachi» 157). Agrega que «los poetas de este grupo atribuyen propiedad y originalidad local a ciertas comidas, de forma tal que la gastronomía se transformaen un bien en disputa entre los saberes del campo y la ciudad...y constituye una defensa contra la homogeneidad centralista que impulsa lo moderno» (159). Cita los casos de poetas como Pablo Neruda, Pablo de Rokha, Violeta Parra, Nicanor Parra, Jorge Teillier, Alberto Rubio, José Angel Cuevas, en quienes «los alimentos se convierten en atrubuto de pertenencia patrimonial» (158). Nuestro trabajo busca ahondar en esta línea que se hace mayoritaria en la poesía de los cincuenta.

\section{Identidad rural y alimentación comunitaria: Violeta Parra, Efraín Barquero y Jorge Teillier}

Como señalamos antes, en los cincuenta, cuando las diferencias entre campo y ciudad se hacen más antagónicas, los alimentos y su origen rural se resignifican como paradigmas de un mundo perdido. Un puente importante entre los poetas adscritos a la búsqueda del origen de este periodo es Violeta Parra (1917-1967), cuyas décimas escritas a solicitud de su hermano Nicanor, anotan su autobiografía en poemas-canciones que relatan su vida, la historia de su familia y las reflexiones que las historias le van suscitando. Como ella misma señala, su canto se vincula con el folclore de Chile y lo separa en canto a lo humano, canto a lo divino, cuecas, tonadas, parabienes, danzas campesinas, cantos con influencia europea, esquinazos y cantos de Navidad. En medio de estas diversas formas del canto popular, la poeta incluye el campo de los alimentos, ya sea de manera directa o a través de metáforas emocionales y reflexivas. En las descripciones, se trata no solo de mostrar la realidad rural en que vivió gran parte de su vida, sino también de representar la abundancia y la escasez alimenticia de los lugares que conoció, con el carácter festivo de la copla popular en octosílabos. Así es como se describe una fiesta en casa de los abuelos de manera pormenorizada: «La cena ya se sirvió/ en una mesa largucha,/ en cada plato, una trucha, / pa'la trucha, un botellón, / pa' la botella un copón, / pa'la copa una galleta; / encima e'una servilleta/ con un plateado cubierto; / como el pescado está muerto/ le asoma ají por la jeta» (V. Parra 37). La descripción del ambiente y los 
alimentos se continúa con el aperitivo, los postres, un nuevo plato de estofado y el escenario de los comensales, el servicio y las diferencias sociales que representan las formas de alimentarse:

Sirven el aperitivo/ p'alentar el apetito, / mistelas y pastelitos / después vendrá el bajativo./ Ya se ven menos altivos/ en el salón elegante,/ porque el vino es abundante/ en el banquete d'estilo/ ¡qué pensarán los pililos, / comiendo guata picante!.../ En este mundo moderno / qué sabe el pobre de queso, / caldo de papa sin hueso./ Menos sabe lo que es terno;/ por casa, callampa, infierno/ de lata y ladrillos viejos. / ¿Cómo le aguanta el pellejo?,/ eso sí que no lo sé./ Pero bien sé que el burgués/ se pit' al pobre verdejo». (37-40)

Otros poemas incorporan el tema a través de la experiencia del viaje por tren: «Pasamos por Longaví, / llegamos a Miraflores / como chirigües cantores;/ abrimos el cocaví. / Los pasajeros allí,/ comieron pollito fiambre,/ después vide los alambres / que séiban y se venían,/ y de repente venía/ de pájaros, un enjambre» (46). Una tercera representación que se reitera en la poeta, es la de la reflexión sobre los avatares de la vida en donde se incluye la imagen alimenticia: «Hay más: en los hospitales / pasa cura'o un enfermo,/ le traen en lindo termo,/ el zumo de los parrales; / el preso pagando males / en un cuartel felizcote,/ de alcohol, un botellonzote/ con el qu'está barnizando,/ un trago de cuando en cuando/ le cruza por el cogote» (56). En Violeta Parra, la comida está signada por la amplificación gozosa del mundo rural y su contracara urbana de pobreza y hambre.

En algunos de los poetas del periodo, los alimentos adquieren el carácter de un imaginario del reencuentro (con la tierra, con la familia, con el origen, con la niñez, con un colectivo perdido o imaginado) y la identificación con una comunidad rural soñada. Tal vez el caso más emblemático es el de Efraín Barquero (1931), hermanado con Jorge Teillier por la raigambre de su poesía con un origen mítico, pero del cual se separa a través de la instauración de los símbolos de la amistad, el compañerismo, el amor y la colectividad en el aquí y el ahora. En esta búsqueda, los alimentos pasan a ser mediaciones esenciales entre yo y el otro, entre el yo y la sociedad. En el poema «Tierra china» (Antología, 2000) se dirá: «El hombre solo vive cuando recupera su semilla/ lo demás es este largo cautiverio de la luna/ esta vieja manera de morir lejos de 
aquellos que nos guardaron / un lugar junto al pan impenetrable» (162). Lo mismo ocurre en el poema «El pan»:

Es blanco el pan, es familiar como la madre; / pero él cuando lo encuentra después de un día de siega/ o después de hacer un surco en el pecho del sol.../ lo descubre negro como un resto de desgracia o un incendio, / lo tacta duro como si su dolor ya lo hubiera forjado,/ lo gusta amargo como si lo hubiera avinagrado su fiebre,/ lo siente triste como si lo llorara su cuerpo envejeciendo, / lo calla avergonzado, como si todos sus hijos lo pidieran, / lo deja, tembloroso, como si se tocara su carne maltratada». (Ibid 23) ${ }^{3}$

El relato de la historia del pan aparece aquí como el relato metonímico de la explotación humana con sus dolores y sus diferencias sociales, pero también está la referencia a la historia personal de un sujeto que se desdobla para enfrentarse a sí mismo en la memoria de la penuria familiar.

En libros como La mesa de la tierra (1998), la pertenencia y el arraigo que se busca se simbolizan en la mesa que es el lugar donde se comen los alimentos y también la tierra que los produce. En poemas como «El brindis» $\mathrm{y}$ «El alimento», la mesa aparece como el lugar de encuentro entre vivos y muertos, entre el pasado y el presente, estableciendo una confluencia del tiempo y el espacio que idealiza la materia y metaforiza los actos cotidianos. En el poema «El cuchillo enterrado», el cuchillo se convierte en el símbolo de un puente entre el intercambio de la vida (cortar el pan para los otros) y el tema de la muerte-regeneración (el sacrificio cristológico) simbolizado por la sangre que fluye del corte:

Coge el viejo cuchillo ennegrecido/ por los años y roído por un gran remordimiento.../ Lo coge y lo entierra mirando a todos lados / sobre un gran pan con un chasquido sordo/ como si atravesara la palma de una mano extendida./ Lo empuña de nuevo y se hace un corte en el muslo/ que embebe con un trozo de ese mismo pan/ como si fuera su comida desde ahora. / Y prueba la sangre de dos heridas abiertas / -la suya y la que nunca se conoce en los otros. (23)

El poema «Tierra china» pertenece al libro El viento de los reinos de 1967, mientras que el poema «El pan» es del primer libro del poeta publicado en 1954, que se titula La piedra del pueblo. 
El cuchillo es también la articulación entre el recuerdo de lo inmemorial y el arraigo en un presente que exorciza la enemistad y el odio y que busca el reencuentro familiar y cultural, como en «La mesa servida»:

Si arrancas el cuchillo del centro de la mesa/ y lo entierras en el muro a la altura del hombre, / estás maldiciendo el pan con su semilla, / estás profanando el cuchillo que usa tu padre/ para rebanarse la mano, para que la sangre sea más pura./ Y los hijos se reconozcan. Y no se oculten de sus hermanos.../ No es una mesa, es una piedra. Tócala en la noche... / Tócala y pídele que vuelva a ser ella misma/ porque si no existiera, no podríamos tocar / el sol con una mano y la luna con la otra. / Y comeríamos a oscuras como los ratones el grano. (9)

Así es como la materialidad de la necesidad alimenticia (pan, semilla, mesa) se convierte en un símbolo de la convivencia humana, al igual como la sangre es la señal del sacrificio de unos por otros. Esto se ratifica en su libro El pan y el vino (2008), que como señala Pierre Mayol son el $a$ priori de la comida. El autor agrega que si el pan representa la dureza de la vida y del trabajo, como el monumento para conjurar el sufrimiento y el hambre, el vino se vincula a la fiesta como marca social, como celebración relacionada con el exceso y la locura (Mayol et al, La invención de lo cotidiano II 88). En el libro de Barquero, los alimentos son el medio a través del cual se da la solidaridad entre el visitante y el visitado, lo que de nuevo ocurre en la mesa-casa-tierra-vida. El pan y la mano que lo sirve se mezclan con su origen, el grano y la semilla cuya genealogía se cuenta en el poema «La cáscara/ el grano» del mismo libro: «El cuarto donde guardaban la semilla era oscuro/ y me cuesta mucho encontrarlo en mis recuerdos. / Era un cuarto como dentro de otro aun más pequeño / donde se oía día y noche/ desprenderse la cáscara del grano» (El pan y el vino 40). La hora del pan y la hora del vino aparecen como esenciales para el ser humano cuando se enfrenta al sacrificio, a la solidaridad o a la traición. Pan y vino consolidan el instante de la celebración, las nupcias, el regocijo del encuentro que fija el instante y que permite remontarse a los orígenes:

$\mathrm{Al}$ comer frente a otro el mismo/ bocado/ nos damos cuenta que/ no podríamos hacerlo sino en una/ mesa donde todos somos iguales/ donde todos tenemos el mismo porte/ donde 
nos confundimos con/ el vapor de la comida/ con el halo/ de nuestro aliento/ al ofrecer el pan/ y el vino a los comensales tú haces / que su semilla no se pudra en la tierra. (20)

Axis mundi de todo llamado y de toda respuesta, la hora del pan y la hora del vino aparecen como parte integral del ser humano enfrentado al sacrificio, a la solidaridad y la traición: «siente que es el mismo un bocado/ donde el pan no se endurece» (35). Pan y vino son también elementos litúrgicos para el reencuentro con la memoria que sostiene la genealogía humana, el padre, la madre y «el calor del único fuego sin ceniza» (40). En su último libro, Pacto de sangre (2009), los alimentos se ligan a una liturgia de regeneración que articula comunidad y comunión a través del sacrificio. A partir de las figuras de la castellana y la india, el poeta desarrolla un movimiento que es un proceso de aprendizaje y reconocimiento entre dos culturas que se comunican de diversas maneras, entre las cuales la alimentación y la comida son fundamentales. En este poemario como en los anteriores de Barquero, el cuchillo representa un símbolo fundamental de la unión o la separación de los seres humanos.

En el poema «El cuchillo de piedra» leemos:«Aun no puedo saber por qué esconde tanto el cuchillo/ no sólo de mí sino de todas las miradas extrañas. / Como si fuera el primero que consagraron sus dioses / cuando decretaron el sacrificio de los animales...Ella también parece esconderse muy adentro de sí misma/ ahí mismo donde sus dioses ocultaron el cuchillo de los hombres» (29). En este libro los símbolos de lo alimenticio son la base de la comunicación y el reconocimiento del otro: enterrar granos en el jardín, beber en la vertiente, el agua de la lluvia, beber leche de las piedras o el sabor del barro. El acto final del sacrificio del cordero une a ambas mujeres a través de la sangre del animal en un acto que se opone al canibalismo y a la antropofagia del dominio, de la represión, de la tortura o de la desaparición del otro: «Ambas mujeres renacen de nuevo al ver el mismo cordero/ que degolló la indiaconvertido en otro aun más hermoso. / Entonces se preparan a celebrar con los demás / Algo entrañable/ algo que tienen en común con los animales/ al dar a luz/ al dar la primera leche/ al dar su cuerpo en alimento» (83).

De esta manera, el poeta desarrolla un movimiento que circula de la castellana a la india y de la india a la castellana desde una diversidad de ritos, pasajes, ceremonias, formas de encuentro que van desde la extrañeza del otro al reconocimiento, de la exclusión a la inclusión, desde 
la indiferencia a la humanización del otro y en donde los alimentos y sus utensilios ocupan una simbolización esencial y ancestral: el cuchillo, la piedra, los granos, el agua, el pan, el vino y finalmente la sangre que al beberse une y hermana.

En el caso de Jorge Teillier (1935-1996), como han señalado diversos críticos (entre ellos el propio autor), su obra descansa en la tradición de la representación lárica (poesía del Lar, del Origen, de la Frontera), aunque trasciende este arraigo en una serie de haces temáticos que se abren en otras direcciones. Sus poemas arrancan del recuerdo «ingenuo» y la nostalgia por la pérdida de un mundo ancestral que representa el paraíso de la infancia, el cual paulatinamente se desintegra y se convierte en pura imagen soñada. Se trata de postular un tiempo de arraigo cuyo cronotopo está en un espacio rural incontaminado, que se preserva en el mito o en la memoria. En 1965, en el texto «Los poetas de los lares. Nueva visión de la realidad en la poesía chilena», el poeta señalaba:

Frente al caos de la existencia social y ciudadana los poetas de los lares...pretenden afirmarse en un mundo bien hecho, sobre todo en el del mundo del orden inmemorial de la aldeas y de los campos, en donde siempre se produce la misma segura rotación de las siembras y cosechas, de sepultación y resurrección [...]. De ahí también la nostalgia de los «poetas de los lares», su búsqueda del reencuentro con una edad de oro, que no se debe confundir sólo con la de la infancia, sino con la del paraíso perdido que alguna vez estuvo sobre la tierra... (Prosas 26)

En su poesía existe el sur mítico y lluvioso de Pablo Neruda, pero desrealizado por una creación verbal en donde los lugares de provincia se tiñen de referencias melancólicas y simbólicas que se hacen universales. El poeta aparece como el sobreviviente de un paraíso perdido, como el soñador visionario de una época dorada de la humanidad que conserva a través de los tiempos el mito y la imagen esencial de las cosas: casa, tierra, árbol (Valente, 1975). Pero el recuerdo ingenuo e incorruptible que se recupera por medio de la memoria se trasciende sólo momentáneamente y culmina en su paulatina desintegración. Frente a ello, se buscan las huellas perdidas para acceder al lugar maravilloso de donde venimos. A través del recuerdo la realidad cotidiana se hace visible y se recupera. Pero ella solamente sobrevive en los lugares del hallazgo, constituido por 
los residuos del pasados y los espacios secretos y ocultos. De acuerdo con Giordano (1966) el poeta recupera dos momentos estéticos: el de la infancia y el del recuerdo. En el poema «Bajo el cielo nacido tras la lluvia», esta felicidad pasajera se hace evidente: «Pues siempre podremos estar en un día que no fue ayer ni mañana,/ mirando el cielo nacido tras la lluvia/ y escuchando a lo lejos / un leve deslizarse de remos en el agua» (108).

Los alimentos, aparecen en Teillier, bajo la forma de dones de la naturaleza que están en ese illo tempore al alcance de la mano para comerlos, contemplarlos o gozarlos como los frutos o los brotes del árbol. Pero también forman parte de la armonía universal de un mundo no contaminado por el tráfago de la modernidad: la chicha de manzana, la harina tostada, las manzanas. El alimento está allí al alcance de la mano como en el paraíso, listo para ser consumido y en Teillier son fundamentalmente las manzanas y la chicha de manzana que proliferan en su región y su infancia: «La sangre de las manzanas/ ilumina la sidrería» (28); «Quién recogerá esas manzanas/ donde aún brilla un sol de otra época?» (29); «Pasea por mi cuarto/ como la sombra desnuda/ de los manzanos en el muro» (48); «Mi padre tenía un gran manzanar. / Había abundancia de manzanas.../No se sufría hambre» (137). Y en otro poema: «Había abundancia de manzanas,/ crecían por todas partes, / los árboles se agachaban hasta el suelo por la abundancia de las frutas. / No se sufría hambre./ El que tenía ganas comía harina tostada y tomaba chicha...» (117). En general, los alimentos naturales aparecen en sus poemas como un entorno maravilloso que enfatiza la armonía, la solidaridad, el amor, la amistad, lo bucólico del paisaje. Así «Esa noche oí caer las nueces desde el nogal» (20); «yo llenaba esas manos de cerezas, esas / manos llenaban mi vaso de vino» (21); «y los almendros no quieren pensar/ en sus negras raíces» (22); «Los pájaros se comían las migas / que sembraba para señalarte el camino» (47); «la sangre blanca de un cerezo/ era el anuncio de nuevas puertas» (132); «Y ahora / voy a pedir otro jarrito de chicha con naranja» (144); «yo oía a los mapuches pregonando cochayuyo» (161); etc. Esta visión armoniosa del mundo cercana a la representación romántica, se distancia más del objeto alimenticio que en los textos de Barquero, aunque a veces también forma parte del intercambio amoroso o la amistad, como en el poema «Sentados frente al fuego»: «Yo llenaba esas manos de cerezas, esas / manos llenaban mi vaso de vino» $(21)$. 
A veces, las menos, algunas formas elementales del alimento se convierten en Teillier en metáforas del desarraigo y de la vida presente, como en el final del poema «Despedida»: «Me despido de la memoria/ y me despido de la nostalgia / -la sal y el agua/ de mis días sin objeto-» (39), donde sal-memoria y agua-nostalgia se convierten en los símbolos de una carencia actual: de un hambre ancestral y simbólica no saciada. En general en esta poesía, los alimentos se presentan en forma pura, como parte de la armonía perenne de ese universo destruido para siempre por el proceso moderno. Las manzanas puestas a guardar, el licor de guindas que preparó la abuela, el olor a café, el maqui de los mendigos, el racimo de uvas, el primer vino que ofrecieron, la caída de las nueces desde el nogal, el olor a pan recién amasado, beber un vaso de cerveza, las mazorcas asoleándose en los techos, el blanco vaso de aguardiente, son todos gestos petrificados en el magnesio fotográfico de una atmósfera imaginada arquetípica, que repite una y otra vez su evocadora imagen de los «dominios perdidos». Estos alimentos que adornan, adjetivan o encuadran el gesto de reconstrucción de la memoria mitificada, solo adquieren un carácter activo en el país de los sueños, donde el poeta convierte el pasado en la rememoración de los amigos muertos, aquellos que se dispersaron «como el polvillo de los duraznos en los dedos» («Señales» 52) o como proyecto futuro: «en mis sueños vienes / atravesando las estaciones.../y al despertar veré que el pan sobre la mesa/ tiene un resplandor más grande...» («Carta de lluvia» 54). Proyecto que a veces adquiere un carácter visionario: «para hablarles del tiempo en que la tierra/ se multiplicará con los panes y los peces / y será de verdad para todos» («Retrato de mi padre, militante comunista»99).

\section{Del origen alimentario a la modernidad degradada: Alberto Rubio y David Rosenmann- Taub}

Alberto Rubio (1928-2002) y David Rosenmann-Taub (1927), de diferentes maneras recurren a imágenes del mundo rural para incursionar en el mundo del origen, también como una crítica frente al proceso de la modernidad. En el caso de la poesía de Rubio, la elaboración de la comida induce a recuperar los lazos con una comunidad rural que se focaliza en los familiares, los amigos, los conocidos y todos aquellos a quienes reúne alrededor de la mesa. Un rasgo fundamental de su obra es 
la manera como logra la personificación de los alimentos, a partir de la visión ingenua del niño que recupera el objeto en su estado prístino. El uso del oxímoron y la extensión de los sentidos interpelan a los alimentos, de una manera tan novedosa que éstos nos penetran por todas partes y desde todas las direcciones. En ese sentido, en su poesía no se habla de la infancia ni de los orígenes sino que el sujeto que habla y el sujeto que lee devienen infancia y origen. Así, en el poema «El almuerzo» de su único libro publicado, La greda vasija (1952), que citamos in extenso por el carácter paradigmático de lo que señalamos, se nos dice:

El almuerzo zapallo nos denuncia. / Su esencia nos traspasa, y en éxtasis quedamos. / heridos y dorados los zapallos, / abren su corazón a un zapallo apetito./ Sus brazos son vapores aromados/ desplegándose al aire./ Los zapallos invitan, heridos y dorados./ El aire se derrite de apetito./ Infinito me vuelvo, denunciado/ de esencia zapallera, almorzador zapallo. $(27)^{4}$

En este poema, el aura del zapallo nos envuelve con una suma de cualidades que no solo incita nuestros sentidos (olor, vista, sabor, color, gusto, tacto, oído, sinestesias), sino que se cualifica (denuncia, éxtasis, heridos, doradas, vapores, apetito) y se personifica hasta simbolizar el almuerzo como una hipérbole de la fruición estética y sensible. Todo esto en medio de un bosque de aliteraciones, onomatopeyas, anáforas y repeticiones que dan origen a una poesía que integra reiteradamente lo natural con lo humano.

En la poesía de Rubio (2000) todo elámbito natural contribuye a relevar la comunión del ser humano con el otro a través de la mesa familiar y la alimentación. En «Mesa del alba», la mesa del desayuno se alegra con el reencuentro de los seres queridos, el diálogo y una integración natural que es celebración gozosa de la vida:

La mesa en la mañana me espera con su silla.../ un hombre al desayuno se lanza con sus dientes... / Es pájaro la lengua de ese hombre sentado./ Y conversa con otro que a su lado se sienta.../ Y así nace el gorjeo matinal de la casa./ ¡A

En este trabajo citamos la reedición del libro realizada por Ediciones Atenea de la Universidad de Concepción en el año 2000. 
dónde brilla un sol que es comedor brillante, / de la cocina vino la vaporosa taza, / desde el mismo horizonte con su día fragante! (21)

Después de la soledad, el desayuno permite el diálogo, que se escenifica como un diálogo de pájaros, con el brillo del sol, la taza vaporosa y el día fragante. Este goce sensual, pleno e integral del sujeto con la naturaleza y la comida, se repite en el poema « Colmado de comida revolcarme en la hierba!», donde la sensualidad corporal y espiritual permea todo el texto. Aquí «comida», «hierba», «sol amarillo», «tierra», «cielo» y «suelo» son indistinguibles de las sensaciones del propio sujeto que se siente en plenitud: «colmado de comida», «revolcarme en la hierba», «entrecerrar los ojos como en acabamiento», «párpados», «sentir la tierra», «quedarme dormido», «rotundamente vivo» (55). Esta simbiosis entre la sensualidad de los sentidos y su reproducción en el mundo natural se focaliza en la noción de la «luz» que aparece en la primera y segunda estrofa para reiterarse acumulativamente en la tercera, iluminando su carácter de gozo exacerbado. En el poema «Sandial» como en «El almuerzo», todos los sentidos del sujeto se hunden en el goce sensual de la sandía, a través de cuyo calado se interna en la memoria de la infancia para recuperar olores y sabores, que incluyen el recuerdo de la madre y la fruición estética del poema:

Por un hondo camino me aproximo a la historia/ que en la honda sandía me sangra frescamente./ Es como hacer alegre calado en la memoria/ recordar a mi madre sandía hundidamente.

Y me hundo profuso en la roja sandía,/ y a mi madre me encuentro, filial en el regazo,/ sentada en el profundo y maduro mediodía:/ ¡todo en senos sandiales el verano le abrazo! (Rubio 49)

De este modo, la visión de la sandía en el recuerdo del sujeto evoca la visión del seno materno con su frescura, sangre filial y calor, abriendo y cerrando el calado de la memoria, para volver a encontrarse con la madre: «encontrarme a mi madre...madurada en frescura que, sandía ¡se cierra!» (49). Así, el calado en la madre-sandía-memoria permite representar el sandial como el cronotopo que recupera el goce orgiástico de la infancia rural así como la comunidad perdida. 
En la poesía de David Rosenmann-Taub (1927), la nostalgia del paraíso perdido es también evidente como soporte de un lenguaje primigenio que se intenta reconstruir en forma insistente y obsesiva para sostener la precariedad de la vida. En esta tarea de exorcizar un presente poblado por el dolor y el vacío, el sujeto de los poemas busca el imaginario de un país más allá en cuya utopía convergen el pasado y el futuro y que se llena con el jardín de la infancia, el amor filial o el reencuentro con la inocencia perdida. En la primera edición de su libro Cortejo y epinicio de 1949, los utensilios y objetos de la cocina adquieren vida propia para interpelar a los sujetos, al mismo tiempo que sirven para rememorar el lugar de la infancia. En el soneto XLVIII, «La taza de café, la cafetera», la enumeración caótica de los utensilios va fermentando una acumulación de recuerdos, que intensifica las sensaciones de la infancia, hasta impregnar los sentidos en el presente y proyectarlos hacia el futuro:

La taza de café, la cafetera, / el vapor que me entibia el esqueleto, / la fragante sartén, el amuleto/ tiznado, la albahaca, la sopera, / el roto lavaplatos, la nevera/ como una madrugada y el coqueto/ jarrón multicolor, el parapeto/ lleno de tarros, azafrán y acelgas...

Todo lo mío/ claro regresa a tu silvestre estera.

En tu vapor, sin fin me desvanezca/ cuando llegue la hora en que no crezca/ oh dichosa cocina, cuando muera... (118)

El vapor de la cafetera ensoñada hacia o desde el pasado, sirve para enhebrar el futuro inevitable desde un presente en que la añoranza de la cocina familiar recobra con fuerza la arcadia perdida. Arcadia que los utensilios de cocina y el vapor de la tetera rememoran e integran con el momento final, el del desvanecimiento del sujeto en la muerte. Esta caracterización de los utensilios de la cocina y el comedor, que evocan un tiempo pretérito en un ámbito rural, personificados y con vida propia, se repite en otros poemas como el VIII, que lleva como subtítulo «El gato coge a una mariposa». En un ambiente nocturno con ciertos visos tenebrosos, los objetos perciben el drama solitario del gato atacando la mariposa, como testigos impotentes del drama:

las alas a la rastra./ Inmensa mariposa, toda gris ligereza,/ navío, antearañazo, despreocupado, gris, / te tronchas y tu vuelo rebota disonante... / El gato te mastica: a las sillas recorre/ un nervioso crujido, las copas tintinean/ roncamente en el trinche, 
las servilletas gritan./ $\mathrm{Y}$ en espantoso acuerdo el comedor se angustia:/ el gato te mastica: oh chirrido espantoso./ Es un lloro estridente, es un lamento eterno/ de cucharas, manteles, platos, alcuzas, vasos... (Rosemann-Taub 37)

La extrañeza del texto es provocada por la caracterización humanizada que adquieren los objetos en sus actitudes de impotencia frente al drama del cual son mudos testigos, como si fueran personas. Esta antropomorfización de los objetos es recurrente en la producción poética del autor y saca sus textos del armónico e idílico ámbito rural de otros poetas del periodo, para enhebrarlos con un presente en que se advierte la presencia ominosa de la muerte, lo que puede apreciarse en los poemas «IV», «Cosecha en sosiego», «Moi vivant», «Canción de cuna», «La lentísima», «Diálogo sepulcral», entre otros.

\section{Colofón: otros poetas}

Hay otros poetas que inician su producción en los cincuenta y que mantienen este repudio al proceso devastador de la modernidad y su reflejo más evidente, el multitudinario, masivo y degradado mundo urbano, incorporando las representaciones alimenticias como un elemento central de su adhesión a los valores de una comunidad perdida. En Delia Domínguez (1931), por ejemplo, muchos poemas aluden a una cotidianidad del mundo campesino perdida en los avatares del tráfago urbano, realidad que se rememora con nostalgia, amor fraterno e incluso ironía. Muchos de los títulos de sus poemas se imbrican con esta actitud: «Caldo de cultivo», "Actos naturales», «Sopa de sémola», "Cuadro de comedor», «Huevo de gallina soltera», «Agua de pariciones», «Sabiduría de gallinero», «Adiós diente de leche», «Leche de mujer», «Agua de hierbas», entre otros. Como puede verse, a través de discursos que se relacionan con la experiencia campestre, la poeta celebra los alimentos como parte de una integración que conforman el mundo natural y el mundo humano. Esta comunión con la naturaleza no se vive como nostalgia sino como una realidad presente que se separa de los procesos de la modernización. Así por ejemplo en el poema «Actos naturales»5:

Los textos de la autora aquí citados pertenecen en la antología La gallina castellana y los huevos (1995). 
«Hoy piqué la tierra de las peonías / y coseché arvejas en la huerta.../ Nada hay seco en los montes, / todo se esfuma/ confundido con el humo de las fogatas lejanas.../ y en la despensa sigue goteando la pulpa/ de membrillo/ para el arrope del invierno» (100).

A veces, como en otros discursos del periodo, asoma también la nostalgia de la infancia y la pérdida irremediable de un mundo que ya no existe, a través de la mención del comedor y de la sopa, como en «Cuadro de comedor»: «El comedor vacío de personas.../ me sube el frío por la espalda / como una lagartija./ (Se fue la mano que extendía el mantel)/ Un plato, un vaso, la sal cristalizada/debajo de mi lengua» (113).

Y en «Sopa de sémola», quien habla rememora con nostalgia, pena y un dejo de angustia la niñez ida:

A lo mejor tres años o cincuenta: el vaho/ encortina los vidrios y vuelve pegajosas las palabras./ Alguien pone la cuchara en tu boca... / Y tragas / aun sabiendo/ que la niñez es apenas un libro descosido,/ una hazaña/ que vuelve de cuando en cuando en la sopa de sémola/ para no morir. (111)

En muchos de los textos de otros poetas como Luis Vulliamy, Rolando Cárdenas, Fernando González Urizar, Marino Muñoz Lagos, Emma Jauch, Pablo Guiñez, Carlos Ruiz Zaldivar o Alfonso Calderón, lo propio se hibridiza en los espacios, los acontecimientos, los personajes y los alimentos a través de una mixtura que delinea las identidades nacionales y regionales, en contra de la corriente dominante del progreso indefinido y la modernización a ultranza. Poemas que representan la angustia frente al proceso avasallador de las modernizaciones que hace desaparecer el universo «idílico» del campo y específicamente del mundo rural de la zona central de Chile. Bengoa (1996) señala que: «La nostalgia es el recuerdo positivamente valorado. Es por ello que se lo desea revivir. Al no ser posible, se produce dolor. La nostalgia es un sentimiento doloroso de pérdida, de la inevitabilidad del tiempo» (10). Y agrega:

(La nostalgia rural) es una paradoja. A pesar de ello, es un elemento central de la cultura chilena. En este país, en su cultura e identidad, en el inconsciente colectivo, la ruralidad tiene una importancia central. La historia social, la historia cultural de Chile, no es comprensible sin su ruralidad ...Algún día entenderemos el mestizaje rural que se fue formando en 
largos depósitos en el secano costero, en los valles internos, en esa mitad del país, en esas provincias del sur agrícola...¿Acaso no nos reconocemos en esos paisajes, en esos pasillo, en esos espacios, en esos dolores, en ese sueño perdido de ver desde la ventana las tumbas de nuestros padres y abuelos? (31-7)

Y la rememoración nostálgica no puede dejar afuera los alimentos, que se constituyen en símbolos que condensan el encuentro con la memoria, «los encuentros entre figuras (ollas, platos, alimentos, mesas, humos, temperaturas, recetas, cuerpos) y significados (cariño, cuidado, recuerdos, hogares, malestares, desencantos y soledades)... en su invitación al sentido» (Hernández 48).

\section{Conclusión}

En los poetas, las formas alimentarias y la comida son también señales, signos, símbolos, metáforas y sentidos de ese mundo perdido que se pretende recuperar y mantener en un presente donde el lazo social se ha extraviado y en un futuro desgarrado por la soledad y la destrucción de la colectividad. En su retorno a los orígenes, los poetas de los cincuenta intentan recuperar el mito de la comunidad perdida ligada a los ritos y liturgias más ancestrales de la alimentación. Como recalca Barquero (2008):

Bebes el vino que nos acerca a los hombres / en tus ojos aparece la primera mirada con que se mira todo dejándolo en su sitio/ así la flor brota de nuevo donde la recuerda la abeja/ el hombre pasa su mano sobre su copa servida acariciando su aroma/ después se toca la frente tratando de acordarse de algo/ de quién nos acordamos cuando probamos el vino en silencio/ al regocijarnos con la comida y la bebida comprendemos por un segundo lo eterno/ lo más inexplicable. (48)

De este modo, el origen y la memoria se reconstruyen a través del símbolo-rito del «vino» que devuelve el arraigo de la identidad más ancestral, aquella en donde los sentidos primordiales (tacto, olores, cenestesias, visualidades, sonidos o silencios) se unen a los sentimientos y las emociones de la amistad, el amor, la alegría y la tristeza. Por medio del acto de «beber»y «comer», en esta poesía, nos devolvemos hacia la solidaridad por y con el otro/a y nos reintegramos a la naturaleza de 
donde provienen todos los alimentos, vinculación que perdimos en el camino de un progreso y una modernidad cada vez más vacía y ajena.

\section{Referencias bibliográficas}

Bajtín, Mijaíl. La cultura popular en la Edad Media y el Renacimiento. Barcelona, Seix Barral Editores, 1974.

Barquero, Efraín. La mesa de la tierra. Santiago de Chile, LOM Ediciones,1998.

__. Antología. Santiago de Chile, LOM Ediciones, 2000.

__. El pan y el vino. Santiago de Chile, LOM Ediciones, 2008.

__. Pacto de sangre. Talca, Editorial Universidad de Talca, 2009.

Bengoa, José. La comunidad perdida. Ensayos sobre identidad y cultura: los desafíos de la modernización en Chile. Santiago de Chile, Ediciones Sur, 1999.

Bourdieu, Pierre. Las reglas del arte. Génesis y estructura del campo literario. Barcelona, Editorial Anagrama, 1995.

De Certeau, Michel, Luce Giard y Pierre Mayol. La invención de lo cotidiano 1. Artes de hacer. México, UIA/ITESO/CEMCA, 1996 y [La invención de lo cotidiano 2. Habitar, cocinar]. México, Universidad Ibeoramericana, 1999.

De Rokha, Pablo. Epopeya del fuego. Antología. Edición de Naín Nómez. Santiago de Chile, Editorial de la Universidad de Santiago, 1995.

Domínguez, Delia. La gallina castellana y otros huevos. Antología. Santiago de Chile, Tacamo Ediciones, 1995.

Giordano, Jaime. «La poesía de Jorge Teillier». Poesía chilena (1960-1965). Santiago de Chile, Ediciones Trilce, 1966, pp. 114-126.

Hernández, Marisela. «Deleites y sinsabores de la comida y el comer: situando el tema». Atenea, no. 496, Primer Semestre 2007, pp. 41-54.

Levy-Strauss, Claude. Mitológicas III. El origen de las buenas maneras en la mesa. México, Fondo de Cultura Económica, 1997.

Mistral, Gabriela. Poesía y prosa. Edición de Jaime Quezada. Caracas, Biblioteca Ayacucho, 1993. 
Neruda, Pablo. Obras completas. Tomo I-II-III. Buenos Aires, Editorial Losada, 1957-1973.

Nómez, Naín. Antología crítica de la poesía chilena. Tomo IV. Santiago de Chile, LOM Ediciones, 2006.

- «La poesía de los cincuenta en Chile y España: escorzo y aproximaciones». Campo de Agramante. Revista de Literatura,no. 7, Primavera-Verano 2007, pp. 85-101.

- «Sobre El pan y el vino de Efraín Barquero. Por una liturgia de la solidaridad». Atenea, no. 498, Segundo Semestre 2008, pp. 143-151.

- «Identidad rural y comunidad mestiza: algunas notas sobre las comidas y bebidas en la poesía chilena». Comidas bastardas. Gastronomía, tradición e identidad en América Latina. Ed. Ángeles Mateo del Pino y Nieves Pascual Soler. Santiago de Chile, Editorial Cuarto Propio, 2013.

- «La poesía de los cincuenta: aproximaciones a una modernidad en disolución». Taller de Letras, no. 34, mayo 2014, pp. 85-96.

Parra, Nicanor. Cancionero sin nombre. Santiago de Chile, Nascimento, 1937.

__. Poemas y antipoemas. Santiago de Chile, Nascimento, 1954.

Parra, Violeta. Décimas. Barcelona, Editorial Pomaire, 1976.

Paz, Octavio. El ogro filantrópico. Barcelona, Seix Barral, 1981.

Rosenmann-Taub, David. Cortejo y epinicio. Santiago de Chile, Cruz del Sur, 1949.

Rubio, Alberto. La greda vasija. Concepción, Cuadernos Atenea, 2000.

Sepúlveda Eriz, Magda. «Ñachi, cazuela, antropofagia y veneno: para una entrada en la imaginación poética alimentaria chilena». Comidas bastardas. Gastronomía, tradición e identidad en América Latina. Ed. Ángeles Mateo del Pino y Nieves Pascual Soler. Santiago de Chile, Editorial Cuarto Propio, 2013, pp. 151-165.

- «Para una entrada en la imaginación poética alimentaria chilena».

Revista Chilena de Literatura, no. 88, Segundo Semestre 2014, pp. 199-213. 
Teillier, Jorge. Los dominios perdidos. Antología.Santiago de Chile: Fondo de Cultura Económica, 1996.

__. Prosas. Santiago de Chile, Editorial Sudamericana, 1999.

Valente, Ignacio (Seudónimo de José Miguel Ibáñez Langlois). Poesía chilena e hispanoamericana actual. Santiago de Chile, Nascimento, 1975. 
